Original Research Paper

\title{
Effect of Complete Feed Silage Made from Agricultural Waste on Milk Yield and Quality of Dairy Cows
}

\author{
Ambo Ako, Syahdar Baba, Fatma, Jamila and Muhammad Rusdy \\ Faculty of Animal Science, Hasanuddin University, \\ Jln. Perintis Kemerdekaan KM. 10 Tamalanrea Makassar, Indonesia
}

Article history

Received: 25-09-2016

Revised: 28-10-2016

Accepted: 04-11-2016

Corresponding Author:

Ambo Ako

Faculty of Animal Science,

Hasanuddin University, Jln.

Perintis Kemerdekaan KM. 10

Tamalanrea Makassar,

Indonesia

E-mail: amboako@yahoo.com

\begin{abstract}
The problem facing dairy cow producers in tropical area is the low availability of proper nutrition, especially during the dry season. One solution to overcome this problem is to utilize technology of Complete Feed (CF) silage using ensiled several local abundant ingredients from agricultural wastes. This study aimed to find a formulation of CF silage from agricultural wastes as forage substitution for dairy cows to increase yield and quality of the milk. The study was conducted on dairy farms in Enrekang District, South Sulawesi of Indonesia. The formulations of CF silage used in the study were tested both in vitro and in vivo and compared with the farmer's practices that using elephant grass plus rice bran. A total of 20 Holstein Friesian dairy cows in 4-5 months lactation with a lactation period of 3rd-5th were used for in vivo study. The treatments were Elephant Grass + Rice Bran (EG-RB), Elephant Grass + Concentrate (EG-CON), Complete Feed Silage made from straws (CF-S) and complete feed silage made from straws and vegetable wastes (CF-VW). The results of this study showed that the dry matter intake and milk yield of dairy cow were higher in EG-CON, CF-S and CF-VW compared to EG-RB and were not different among EG-CON, CF-S and CF-VW. The crude protein, lactose, calcium and phosphorus of the milk were higher in the EG-CON, CF-S and CF-VW than EG-RB and were not different among EG-CON, CF-S and CF-VW. Fat content, density and $\mathrm{pH}$ of the milk were not different among treatments. In conclusion, in order to maintain and to improve the yield and quality of milk in dairy cows, the agriculture wastes, such as straws and vegetable wastes can be used as the basal feed of dairy cows for fodder substitution in the form of CF silage.
\end{abstract}

Keywords: Agricultural Waste, Dairy Cow, Complete Feed, Milk Yield and Quality

\section{Introduction}

The development of the dairy cow population in Indonesia tends to increase from year to year, but the problem is the availability of high feed quality and low production and quality of milk produced. In Enrekang District, South Sulawesi of Indonesia, dairy cows population increased from 500 heads in 2005 to 1,530 heads in 2010 (DPPE, 2011). The consequence of increased population is lack forage availability, especially during the dry season, so the milk production decreased significantly. During the dry season most farmers only use rice straw or corn straw as a source of forage without any processing for increasing its nutritional value (Baba et al., 2011).
Furthermore Muktiani (2007) revealed that the main parts of dairy feeding are basically consist of roughage as the main feed and concentrates as a feed supplement. Source of roughage could be from grass, legume and agricultural waste, while the concentrates feed are generally consist of a mixture of feed materials as a source of energy and protein with a crude protein content $>18 \%$ and crude fiber $<18 \%$.

Baba et al. (2011) reported that the availability of agricultural waste from food crops or from horticulture is quite plentiful in Enrekang. In the area of food crops, some agricultural wastes such as rice straw, corn straw and peanut straw, while in the horticulture area cabbage waste, carrots waste, coffee husk and corn straw are plentiful that can be used as a source of the roughage to 
substitute of elephant grass. Generally, these agricultural wastes are low quality and the quality can be improved by mixing them with high quality but low prices of agro-industrial by product like rice bran, corn meal and coconut cake in the form Complete Feed (CF). This CF is expected can increase the milk production (Pangestu et al., 2003; Ramli et al., 2009). By proper formulation, it is expected that $\mathrm{CF}$ can meet the need for essential nutrients by animals. Moreover, the provision of CF to beef cattle is economically more favorable compared to conventional feeding (Mayulu et al., 2009), because CF technology can reduce the use of labor and feeding time (Baba et al., 2011). The ensiling of CF using local feed ingredients, the shortage of feed during the dry season may be can be alleviated.

In the tropical areas, increasing the availability of feed during the dry season can be conducted through hay and silage making. Because uncertainty of the weather during the growth season in the tropics, silage making may be more suitable to be used to conserve nutrients in the feed. By ensiling CF, more nutrients needed by animal like energy, protein and vitamin can be conserved.

One solution to overcome the low quality of agricultural wastes is to utilize CF technology by mixing the agricultural wastes with the high quality feed sources. The provision of complete feed to beef cattle is economically more favorable compared to conventional feed (Mayulu et al., 2009), because CF technology can reduce the use of labor and feeding time (Baba et al., 2011). By proper feed formulation, it is expected that the CF can meet the needs of essential nutrients by dairy cow. If the $\mathrm{CF}$ technology using local ingredients can be developed in Enrekang, the shortage of fodder can be alleviated. Wahjuni and Bijanti (2006) showed that the CF did not affect the performance of the liver and kidneys of dairy cows indicating that it was safe to be continuously used as feed. Similarly, the research of Mukodiningsih et al. (2008) showed that the use of CF to the calf starter caused rumen growth remains good in dairy calves.

This study was carried out to find a CF formulation with cheap local feed ingredients to substitute forage to increase the milk yield and quality of dairy cows.

\section{Materials and Methods}

The study was conducted on dairy farms in Enrekang District, South Sulawesi of Indonesia. The site was located at $3^{\circ} 33^{\prime} 57^{\prime \prime} \mathrm{S}$ latitude and 119 47’31" E longitude at altitude about $1300 \mathrm{~m}$ above sea level with a daily average temperature of approximately $27.34^{\circ} \mathrm{C}$. The climate of this area is tropical monsoon characterized by rainy season during November to June and dry season during July to November.

The feed ingredients that used in this study were agricultural wastes from food crops and horticulture areas. In the food crops area, the sources of fibre for $\mathrm{CF}$ were rice straw and corn straw while the energy source obtained from rice bran and corn meal. Coconut cake was used as source of protein. In horticultural area, the sources of fibre for CF were corn straw, carrots waste, cabbage waste and coffee husk while the energy source using rice bran and corn meal. Coconut cake and tofu waste were used as source of protein.

Based on nutritional content of all feed materials, the $\mathrm{CF}$ formulations were prepared according to the feed requirements of dairy cows for milk production of at least $10 \mathrm{~kg} / \mathrm{head} /$ day (NRC, 2001). Feed materials from the fibre sources were cut into small pieces and mixed with a source of energy, protein and mineral. The formulated of $\mathrm{CF}$ was put in plastic drums to be ensiled in an anaerobic condition during three weeks. After ensiling, the physical characteristic and chemical compositions of CF silage were analyzed.

Twenty Holstein Friesian dairy cows of 4-5 months in lactation with a lactation period of $3 \mathrm{rd}-5$ th were used for in vivo study. The study was arranged according to completely randomized design, consisted of 4 treatments and 5 replications. The treatments of the study are as follows:

- EG-RB = Elephant grass + rice bran (dairy cow farmer treatment)

- $\quad \mathrm{EG}-\mathrm{CON}=$ Elephant grass + concentrate

- $\mathrm{CF}-\mathrm{S}=$ Complete feed silage made from straw

- $\mathrm{CF}-\mathrm{VW}=$ Complete feed silage made from straw and vegetable waste

The composition and nutrient content of the feed for each treatment are shown in Table 1-4, respectively. The Total Digestible Nutrients (TDN) and Crude Protein (CP) content of feed ingredients in this research had met the requirement of dairy cows with body weight $350-400 \mathrm{~kg}$ for milk production of $10-15 \mathrm{~kg} / \mathrm{head} /$ day (NRC, 2001).

The formulated feed and drinking water was given $a d$ libitum to dairy cows in the morning and afternoon. The parameters measured were Dry Matter Intake (DMI), milk yield and quality. Feed intake obtained from the amount of one day consumption $(24 \mathrm{~h})$. Adaptation period lasted during 7 days and the milk yield was measured during 10 days. The $\mathrm{CP}$, fat, lactose, calcium (Ca), phosphorus (P), $\mathrm{pH}$ and density of milk were analyzed. CP concentration was analyzed by Indirect Kjeldahl method (method 991.23; AOAC International, 2005) while fat by Babcock method (method 989.04; AOAC International, 2005), lactose by Nelson Somogy method (Sudarmadji et al., 1997), Ca and P by Atomic Absorption Spectrophotometric and Colorimetric methods (method 991.25; AOAC International, 2005). $\mathrm{pH}$ was analyzed using a $\mathrm{pH}$-meter and density by Lactodensimeter. 
Table 1. Composition and nutrient content for EG-RB treatment

\begin{tabular}{|c|c|c|c|c|c|c|c|c|c|}
\hline \multirow[b]{2}{*}{ Feed ingredients } & \multicolumn{9}{|l|}{$\%$} \\
\hline & Composition & TDN & Ash & $\mathrm{CP}$ & Fat & $\mathrm{CF}$ & NFE & $\mathrm{Ca}$ & $\mathrm{P}$ \\
\hline Elephant grass & 45 & 23.6 & 5.40 & 3.91 & 1.22 & 14.5 & 19.9 & 0.21 & 0.16 \\
\hline Rice bran & 55 & 37.4 & 7.48 & 7.15 & 4.76 & 7.65 & 28.0 & 0.06 & 0.77 \\
\hline Total & 100 & 61.0 & 12.9 & 11.1 & 5.98 & 22.2 & 47.9 & 0.27 & 0.93 \\
\hline
\end{tabular}

Table 2. Composition and nutrient content for EG-CON treatment

\begin{tabular}{|c|c|c|c|c|c|c|c|c|c|}
\hline \multirow[b]{2}{*}{ Feed ingredients } & \multicolumn{9}{|l|}{$\%$} \\
\hline & Composition & TDN & Ash & $\mathrm{CP}$ & Fat & $\mathrm{CF}$ & NFE & $\mathrm{Ca}$ & $\mathrm{P}$ \\
\hline Elephant grass & 45 & 23.6 & 5.40 & 3.91 & 1.22 & 14.5 & 19.9 & 0.21 & 0.16 \\
\hline Rice bran & 20 & 13.6 & 2.72 & 2.60 & 1.73 & 2.78 & 10.2 & 0.02 & 0.28 \\
\hline Corn meal & 5 & 4.04 & 0.11 & 0.54 & 0.21 & 0.13 & 4.01 & 0.01 & 0.02 \\
\hline Coconut cake & 30 & 23.6 & 2.47 & 6.39 & 3.27 & 4.26 & 13.6 & 0.07 & 0.20 \\
\hline Total & 100 & 64.8 & 10.7 & 13.4 & 6.43 & 21.7 & 47.7 & 0.31 & 0.66 \\
\hline
\end{tabular}

Table 3. Composition and nutrient content for CF-S treatment

\begin{tabular}{|c|c|c|c|c|c|c|c|c|c|}
\hline \multirow[b]{2}{*}{ Feed ingredients } & \multicolumn{9}{|l|}{$\%$} \\
\hline & Composition & TDN & Ash & $\mathrm{CP}$ & Fat & $\mathrm{CF}$ & NFE & $\mathrm{Ca}$ & $\mathrm{P}$ \\
\hline Rice straw & 10 & 4.32 & 1.69 & 0.42 & 0.15 & 3.25 & 4.50 & 0.04 & 0.03 \\
\hline Corn straw & 35 & 21.0 & 3.57 & 3.47 & 0.62 & 9.59 & 17.8 & 0.43 & 0.04 \\
\hline Rice bran & 20 & 13.6 & 2.72 & 2.60 & 1.73 & 2.78 & 10.2 & 0.02 & 0.28 \\
\hline Corn meal & 5 & 4.04 & 0.11 & 0.54 & 0.21 & 0.13 & 4.01 & 0.01 & 0.02 \\
\hline Coconut cake & 30 & 23.6 & 2.47 & 6.39 & 3.27 & 4.26 & 13.6 & 0.07 & 0.20 \\
\hline Total & 100 & 66.6 & 10.6 & 13.4 & 5.98 & 20.0 & 50.1 & 0.57 & 0.57 \\
\hline
\end{tabular}

Table 4. Composition and nutrient content for CF-VW treatment

\begin{tabular}{llllllllll}
\hline & \% & & & & & & & & \\
& - & & & & & & \\
Feed ingredients & Composition & TDN & Ash & CP & Fat & CF & NFE & Ca & P \\
\hline Cabbage waste & 2 & 1.52 & 0.24 & 0.43 & 0.07 & 0.26 & 1.01 & 0.01 & 0.01 \\
Carrots waste & 2 & 1.83 & 0.29 & 0.29 & 0.29 & 0.12 & 1.01 & 0.01 & 0.02 \\
Coffee husk & 8 & 4.58 & 0.71 & 0.57 & 0.31 & 2.26 & 4.15 & 0.00 & 0.00 \\
Corn straw & 45 & 27.0 & 4.59 & 4.46 & 0.80 & 12.3 & 22.8 & 0.56 & 0.05 \\
Coconut cake & 16 & 12.6 & 1.32 & 3.41 & 1.74 & 2.27 & 7.26 & 0.04 & 0.11 \\
Corn meal & 2 & 1.62 & 0.04 & 0.22 & 0.09 & 0.05 & 1.60 & 0.00 & 0.01 \\
Rice bran & 20 & 13.6 & 2.72 & 2.60 & 1.73 & 2.78 & 10.2 & 0.02 & 0.28 \\
Tofu waste & 5 & 3.90 & 0.26 & 1.52 & 0.02 & 1.11 & 1.63 & 0.01 & 0.06 \\
Total & 100 & 66.7 & 10.2 & 13.5 & 5.05 & 21.2 & 49.7 & 0.65 & 0.54 \\
\hline
\end{tabular}

The data collected were entered and organized in the excel spread sheet and then it were analyzed using descriptive statistics and GLM-Multivariate (SPSS, version 21) except for the data of physical characteristic and chemical composition of CF silage.

\section{Results and Discussion}

\section{Physical Characteristics and Chemical Composition of Complete Feed Silage}

Physical characteristics and chemical compositions of CF silage are presented in Table 5 . Table 5 shows that the CF silage made from agricultural waste had no any fungus, acid smell and the color was brownish green that similar with original ingredients of CF. The numbers of lactic acid bacteria in CF-S and CF-VW were $6.7 \times 10^{7}$ and $1.1 \times 10^{7}$, respectively. Based on the physical characteristic and the number of bacteria $\mathrm{CF}$ silage had met the standards of good CF silage (Ramli et al., 2009). As expected, the CP contents of CF-S of 13.9 and $13.6 \%$ in CF-VW had met standards for dairy cows feeding with body weight $350-400 \mathrm{~kg}$ for milk production of $10-15 \mathrm{~kg} / \mathrm{head} /$ day (NRC, 2001). 
Table 5. Physical characteristics and chemical compositions of each treatment

\begin{tabular}{lllll}
\hline $\begin{array}{l}\text { Physical and chemical } \\
\text { characteristics }\end{array}$ & EG-RB & EG-CON & CF-S & CF-VW \\
\hline pH & 6.7 & 6.5 & 3.4 & 3.8 \\
Smell & No & No & Acid smell & Acid smell \\
Color & Green & Green & Brownish green & Brownish green \\
Lactic acid bacteria & No & No & $6.7 \times 10^{7}$ & $1.1 \times 10^{7}$ \\
Fungus & No & No & No & No \\
Crude protein (\%) & 11.1 & 13.4 & 13.9 & 13.6 \\
Crude fiber (\%) & 22.2 & 21.7 & 31.2 & 30.5 \\
Nitrogen free extract (\%) & 47.9 & 47.7 & 39.7 & 36.6 \\
\hline
\end{tabular}

Table 6. Feed intake and milk yield in each treatment

\begin{tabular}{lllllll}
\hline & \multicolumn{1}{l}{ Treatments } & & & \\
& - & & & \\
Parameters & EG-RB & EG-CON & CF-S & CF-VW & SEM & $P$ \\
\hline Dry matter intake (kg/head/day) & $8.01^{\mathrm{a}}$ & $9.53^{\mathrm{b}}$ & $9.62^{\mathrm{b}}$ & $9.94^{\mathrm{b}}$ & 0.236 & 0.007 \\
Milk yield (kg/cow/day) & $7.36^{\mathrm{a}}$ & $9.06^{\mathrm{b}}$ & $9.38^{\mathrm{b}}$ & $9.07^{\mathrm{b}}$ & 0.265 & 0.014 \\
\hline
\end{tabular}

Different superscripts in the same row indicate significant difference $(\mathrm{p}<0.05)$

Table 7 . The average of milk yield and quality of dairy cows in each treatment

\begin{tabular}{|c|c|c|c|c|c|c|}
\hline \multirow[b]{2}{*}{ Parameters } & \multicolumn{4}{|c|}{ Treatments } & \multirow[b]{2}{*}{ SEM } & \multirow[b]{2}{*}{$P$} \\
\hline & EG-RB & EG-CON & CF-S & CF-VW & & \\
\hline Crude protein $(\%)$ & $1.45^{\mathrm{a}}$ & $2.97^{\mathrm{b}}$ & $3.20^{\mathrm{c}}$ & $2.86^{\mathrm{b}}$ & 0.159 & 0.000 \\
\hline Fat $(\%)$ & $4.57^{\mathrm{a}}$ & $3.41^{\mathrm{a}}$ & $4.16^{\mathrm{a}}$ & $4.03^{\mathrm{a}}$ & 0.159 & 0.061 \\
\hline Lactose (\%) & $2.18^{\mathrm{a}}$ & $3.07^{b}$ & $2.94^{\mathrm{b}}$ & $2.88^{\mathrm{b}}$ & 0.102 & 0.002 \\
\hline Calcium (\%) & $0.12^{\mathrm{a}}$ & $0.24^{\mathrm{b}}$ & $0.28^{\mathrm{b}}$ & $0.29^{\mathrm{b}}$ & 0.024 & 0.038 \\
\hline Phosphorus (\%) & $0.06^{\mathrm{a}}$ & $0.11^{\mathrm{b}}$ & $0.11^{\mathrm{b}}$ & $0.11^{\mathrm{b}}$ & 0.006 & 0.001 \\
\hline Density & $1.03^{\mathrm{a}}$ & $1.03^{\mathrm{a}}$ & $1.03^{\mathrm{a}}$ & $1.03^{\mathrm{a}}$ & 0.000 & 0.762 \\
\hline $\mathrm{pH}$ & $6.5^{\mathrm{a}}$ & $6.5^{\mathrm{a}}$ & $6.5^{\mathrm{a}}$ & $6.5^{\mathrm{a}}$ & & \\
\hline
\end{tabular}

Different superscripts in the same row indicate significant difference $(\mathrm{p}<0.05)$

\section{Feed Intake and Milk Yield}

Feed intake and milk yield of dairy cows in each treatment are shown in Table 6. The data in Table 6 shows that the Dry Matter Intake (DMI) was higher in EG-CON, CF-S and CF-VW treatments compared with EG-RB treatment, however there was no difference among EG-CON, CF-S and CF-VW treatments. This might be attributed to the low the dietary CP in EG-RB treatment compared with another treatment (Table 1-4). According to Aschemann et al. (2012) that the dietary $\mathrm{CP}$ as low as $12 \%$ depressed nutrient digestibility and microbial protein synthesis in the rumen. The DMI and milk production were decreased when feeding of metabolizable protein deficient diets (Lee et al., 2011; 2012a). On the contrary, when DMI did not decrease, milk production was also not different from diets with adequate metabolizable protein (Lee et al., 2012b; Giallongo et al., 2015).

The milk yield of dairy cows (Table 6) was higher in EG-CON, CF-S and CF-VW treatments compared with EG-RB treatment and were not different among EG$\mathrm{CON}, \mathrm{CF}-\mathrm{S}$ and CF-VW treatments. The result indicated that the agricultural wastes (straws and vegetable wastes) can be used as the main feed for dairy cows to substitute elephant grass forage. The results of the present study are in agreement with Combellas and Martinez (1982) that dairy cows fed mixture of elephant grass and concentrate with crude protein content of $14.7 \%$ resulted in milk yield of $8.8 \mathrm{~kg} / \mathrm{cow} /$ day. This milk yield is also is in agree with Belhadia and Yakhlef (2013) who reported the milk yield of $9.78 \mathrm{~kg} / \mathrm{cow} /$ day and Abdelaziz et al. (2013) with milk yield of $10.71 \mathrm{~kg} / \mathrm{cow} /$ day.

In the present study, concentrate had positive effects on milk production and quality. The effectiveness of concentrate supplementation in the feeding system of dairy cows depends on forage crops, in which forage alone may not satisfy the nutritional requirements of high producing dairy cows because of its low quality (Intisar et al., 2012). However, the amount of concentrate supplementation should consider the economics of feeding. Wanapat et al. (2011) revealed the importance of various protein sources for feed in lactating dairy cows.

For maintaining and increasing the productivity of dairy cows especially during the dry season when the forage availability was limited, applying CF method for feeding of dairy farm can reduce labor and feeding time 
by $72 \%$ (Suharto, 2004). Feeding with CF silage from agricultural waste give another advantages, i.e., no competition between resource utilization for animal feed and for human food sources and reduce land use conflicts with other sectors mainly agric-food sector (Haryanto, 2009). Through CF silage technology formulated from agricultural waste such as corn straw, rice straw and wastes from the markets does not reduce the milk yield and quality. In fact, several studies have shown that the $\mathrm{CF}$ silage made from rice straws could increase milk production (Yusof et al., 1998).

\section{Milk Quality}

The CP of milk was higher in CF-S treatment compared with EG-RB, EG-CON and CF-VW treatments (Table 7). CP content in EG-CON and CFVW treatments were higher than EG-RB treatment, while $\mathrm{CP}$ content of EG-CON and CF-VW treatments was not different. The higher $\mathrm{CP}$ content in the milk of dairy cows in EG-CON, CF-S and CF-VW treatments compared to EG-RB treatment might be due to the higher $\mathrm{CP}$ contents in EG-CON, CF-S and CF-VW treatments compared to EG-RB. In the present study, feed formulation in the EG-CON, CF-S and CF-VW treatments have met the standard requirements for $\mathrm{CP}$ of dairy cows as recommended by the NRC (2001), especially on protein and carbohydrates. Dairy cows fed elephant grass plus rice bran only may be not met the needs of protein of dairy cows.

In the present study, the milk fat content, density and $\mathrm{pH}$ did not differ among treatments (Table 7). Broderick (2003) reported that the fat content of milk was not affected by the level of dietary protein. The results of current study are in agree with Combellas and Martinez (1982) that mixture of elephant grass and concentrate with CP of $14.7 \%$ fed to dairy cows resulted in milk CP and fat contents of 3.1 and $3.9 \%$, respectively.

The lactose, $\mathrm{Ca}$ and $\mathrm{P}$ of milk were higher in EGCON, CF-S and CF-VW treatments compared with EG$\mathrm{RB}$ treatment and were not different among EG-CON, CF-S and CF-VW treatments (Table 7). Higher $\mathrm{Ca}$ and $\mathrm{P}$ content of the milk in the EG-CON, CF-S and CF-VW treatments may be due to the mineral needs of dairy cows are sufficient in this treatments, especially $\mathrm{Ca}$ and P. Dairy cows in EG-CON, CF-S and CF-VW treatments obtained the source of $\mathrm{Ca}$ and $\mathrm{P}$ from a wide variety of feedstuffs such as concentrate, compared with in EG-RB treatment in which the dairy cows were only obtained feed ingredients of elephant grass and rice bran which contain low levels of $\mathrm{Ca}$ and $\mathrm{P}$.

Based on some parameters relating to the milk quality of dairy cows, it can be assumed that the milk quality of dairy cows is generally better in EG-CON, CF-S and CF-VW treatments in comparison to EG-RB treatment and generally there were no differences among EG-CON, CF-S and CF-VW treatments. Thus the agricultural wastes such as straws and vegetable wastes can be used as a substitute for elephant grass in the form of CF silage, in an effort to improve the milk quality of dairy cows.

\section{Conclusion}

The physical characteristic and chemical compositions of CF silage formulated from agricultural wastes such as straws, vegetable wastes and mixed with agro-industrial by products can meet the standard for requirements of dairy cows. The $\mathrm{CF}$ silage was able to maintain and to improve the milk yield and quality of dairy cows. Thus, the agricultural wastes such as straws and vegetable wastes mixed with agro-industrial by products can be used as the basal feed of dairy cows for forage substitution in the form of CF silage.

\section{Acknowledgement}

The author would like to express gratitude to Directorate General of Higher Education, Ministry of Education and Culture Republic of Indonesia for providing funds for this research. We would like to thank farmer groups in Enrekang District for their permission to work with their dairy cows and their participation in the research.

\section{Author's Contributions}

Ambo Ako: Designed, conducted the experiments, analyzed the data and wrote the manuscript.

Syahdar Baba: Performed the experiments and wrote the manuscript.

Fatma: Performed the experiments and analyzed the nutrient of feed ingredients.

Jamila: Performed the experiments and analyzed the milk quality.

Muhammad Rusdy: Aiding wrote the manuscript.

\section{Ethics}

This manuscript has not been published or presented elsewhere in part or in entirely and is not under the consideration by another journal. All the authors have approved the manuscript and agree with submission to the esteemed journal. There are no conflicts of interest to be declared.

\section{References}

Abdelaziz, B., H.E. Bouriache and L. Farida, 2013. Effect of stage of lactation on the physicalchemical quality of milk from Holstein cows in the eastern region of Algeria. Livestock Res. Rural Dev. 
AOAC International, 2005. Official Methods of Analysis. 18th Edn., AOAC International, Washington, DC.

Aschemann, M., P. Lebzien, L. Hüther, S. SDöll and K.H. Südekum et al., 2012. Effect of niacin supplementation on digestibility, nitrogen utilisation and milk and blood variables in lactating dairy cows fed a diet with a negative rumen nitrogen balance. Arch. Anim. Nutrit., 66: 200-214. PMID: 22724166

Baba, S., A. Muktiani, A. Ako and M.I.A. Dagong, 2011. Variety and need of feed technology of smallscale dairy farmer in Enrekang regency, J. Anim. Sci. Technol., 34: 146-154.

DOI: $10.5398 /$ medpet.2011.34.2.146

Belhadia, M.A. and H. Yakhlef, 2013. Milk production and reproduction in dairy cattle farms in the semiarid region: the "haut Cheliff" plains in northern Algeria. Livestock Res. Rural Dev.

Broderick, G.A., 2003. Effects of varying dietary protein and energy levels on the production of lactating dairy cows. J. Dairy Sci., 86: 1370-1381. DOI: $10.3168 /$ jds.S0022-0302(03)73721-7

Combellas, J. and N. Martinez, 1982. Intake and milk production in cows fed chopped Elephant grass (Pennisetum purpureum) and concentrate. Tropical Anim. Product., 7: 57-60.

DPPE, 2011. Laporan akhir tahun dinas peternakan dan perikanan kabupaten enrekang. Dinas Peternakan dan Perikanan Enrekang, Enrekang Sulawesi Selatan Indonesia.

Giallongo, F., J. Oh, T. Frederick, H. Weeks and A.N. Hristov et al., 2015. Effects of slow-release urea and rumen-protected methionine and histidine on performance of dairy cows. J. Dairy Sci., 98: 3292-3308. DOI: 10.3168/jds.2014-8791

Haryanto, B., 2009. Inovasi teknologi pakan ternak dalam sistem integrasi tanaman-ternak bebas limbah mendukung upaya peningkatan produksi daging. Pengembangan Inovasi Pertanian, 2: 163-176.

Intisar, Y.T., A.M. Mawhip, E.K. Muna, S.A. Miriam and M.E. Omer et al., 2012. Effect of feeding systems on milk yield and composition of local and cross bred dairy cows. Int. J. Sci. Technol., 2: 5-9.

Lee, C., A.N. Hristov, K.S. Heyler, T.W. Cassidy and M. Long et al., 2011. Effects of dietary protein concentration and coconut oil supplementation on nitrogen utilization and production in dairy cows. J. Dairy Sci., 94: 5544-5557.

DOI: $10.3168 /$ jds.2010-3889

Lee, C., A.N. Hristov, T.W. Cassidy, K.S. Heyler and H. Lapierre et al., 2012a. Rumen-protected lysine, methionine and histidine increase milk protein yield in dairy cows fed a metabolizable protein-deficient diet. J. Dairy Sci., 95: 6042-6056.

DOI: $10.3168 /$ jds.2012-5581
Lee, C., A.N. Hristov, T.W. Cassidy, K.S. Heyler and H. Lapierre et al., 2012b. Effects of metabolizable protein supply and amino acid supplementation on nitrogen utilization, milk production and ammonia emissions from manure in dairy cows. J. Dairy Sci., 95: 5253-5268.

DOI: $10.3168 /$ jds.2012-5366

Mayulu, H., B. Suryanto, Sunarso, M. Christiyanto and F.I. Ballo et al., 2009. Kelayakan penggunaan complete feed berbasis jerami padi amofer pada peternakan sapi potong. J. Indonesian Tropical Anim. Agric., 34: 74-80.

Mukodiningsih, S.S., S.P.S. Budhi, A. Agus and Haryadi, 2008. Pengaruh variasi pakan sumber protein dan neutral detergent fiber dalam complete calf starter terhadap indicator perkembangan etikulo rumen. J. Indonesian Tropical Anim. Agric., 33: 132-138.

Muktiani, A., 2007. Pemberian jerami terolah dan limbah sayur pasar serta suplementasi Zn-Proteinat untuk sapi Peranakan Onggole. Laporan Penelitian. Fakultas Peternakan Universitas Diponegoro, Semarang.

NRC, 2001. Nutrient Requirements of Dairy Cattle. 7th Edn., National Research Council, Washington, DC.

Pangestu, E., T. Toharmat and U.H. Tanuwiria, 2003. Nilai nutrisi ransum berbasis limbah industri pertanian pada sapi perah laktasi. J. Indonesian Tropical Anim. Agric., 28: 166-171.

Ramli, N., M. Ridla, T. Toharmat and L. Abdullah, 2009. Produksi dan kualitas susu sapi perah dengan pakan silase ransum komplit berbasis sumber serat sampah sayuran pilihan. J. Indonesian Tropical Anim. Agric., 34: 36-41.

Sudarmadji, S., B. Haryono and Suhardi, 1997. Prosedur Analisa untuk Bahan Makanan dan Pertanian. Liberty, Yogyakarta.

Suharto, M., 2004. Dukungan teknologi pakan dalam usaha sapi potong berbasis sumberdaya lokal. Lokakarya Nasional Sapi Potong. Jakarta.

Wahjuni, R.S. and R. Bijanti, 2006. Uji efek samping formula pakan komplit terhadap fungsi hati dan ginjal pedet sapi Frisien Holstein. Media Kedokteran Hewan, 22: 174-179.

Wanapat, M., K. Boonnop, C. Promkot and A. Cherdthong, 2011. Effects of alternative protein sources on rumen microbes and productivity of dairy cows. Maejo Int. J. Sci. Technol., 5: 13-23.

Yusof, S.M., H. Fadzil, K.H. Teoh and S. Abbas, 1998. Early weaning of calves on milk replacer fed either soyabean or fishmeal-based calf starter. Malaysia J. Anim. Sci., 3: 40-46. 